\title{
Fraksi Serat Pelet Silase Pelepah Kelapa Sawit (Elaeis guineensis) dan Indigofera (Indigofera zollingeriana) dengan Komposisi yang Berbeda
}

\author{
(Fibre Fraction of Oil Palm Frond and Indigofera Silage with Different Composition)
}

\author{
Ali A, Tarmizi M, Febrina D \\ Program Studi Peternakan, Fakultas Pertanian dan Peternakan, UIN Sultan Syarif Kasim Riau \\ Kampus II Raja Ali Haji. Jl. Subrantas Km. 15, Pekanbaru, 28293 \\ ali_arsyadi@yahoo.com
}

\begin{abstract}
The aim of study was to determine the effect of Indigofera zollingeriana supplementation on neutral detergent fibre (NDF), acid detergent fibre (ADF) and acid detergent lignin (ADL) of silage pellet made from oil palm frond. This research was done in a completely randomized design (CRD) consists of 5 treatments and 3 replications. They are A: Oil palm fronds $(100 \%)+I$. zollingeriana $(0 \%)+1.3 \mathrm{ml}$ of probiotic/kg substrate; $\mathrm{B}$ : Oil palm fronds $(85 \%)+$ I. zollingeriana $(15 \%)+1.3 \mathrm{ml}$ of probiotic/kg substrate; C: Oil palm fronds $(70 \%)+$ I. zollingeriana $(30 \%)+1.3$ $\mathrm{ml}$ of probiotic/kg substrate; D: Oil palm fronds $(55 \%)+$ I. zollingeriana $(45 \%)+1.3 \mathrm{ml}$ of probiotic/kg substrate; and E: Oil palm fronds $(0 \%)+$ I. zollingeriana $(100 \%)+1.3 \mathrm{ml}$ of probiotic/kg substrate. The results of study showed that NDF, ADF and ADL content of silage pellet made from oil palm frond were significantly $(\mathrm{P}<0.05)$ higher than silage pellet made from $I$. zollingeriana. Supplementation of $I$. zollingeriana at 30 and $45 \%$ level significantly $(\mathrm{P}<0.05)$ reduced NDF, ADF and ADL content of silage pellet made from oil palm frond. The conclution of this study, that increasing the proportion of I. zollingeriana up to $45 \%$ lead NDF, ADF and ADL content of silage pellet made from oil palm frond are getting lower.
\end{abstract}

Key Words: Oil Palm Frond, Indigofera zollingeriana, Fibre Fraction

\begin{abstract}
ABSTRAK
Penelitian ini bertujuan untuk mengetahui pengaruh penambahan Indigofera zollingeriana terhadap kandungan neutral detergent fibre (NDF), acid detergent fibre (ADF) dan acid detergent lignin (ADL) pelet silase berbahan dasar pelepah kelapa sawit. Penelitian ini menggunakan rancangan acak lengkap yang terdiri dari 5 perlakuan dan 3 ulangan, yaitu A: Pelepah kelapa sawit $(100 \%)+$ I. zollingeriana $(0 \%)+1,3 \mathrm{ml}$ probiotik/kg substrat; B: Pelepah kelapa sawit $(85 \%)+I$. zollingeriana $(15 \%)+1,3 \mathrm{ml}$ probiotik $/ \mathrm{kg}$ substrat; C: Pelepah kelapa sawit $(70 \%)+I$. zollingeriana $(30 \%)+1,3 \mathrm{ml}$ probiotik $/ \mathrm{kg}$ substrat; D: Pelepah kelapa sawit $(55 \%)+I$. zollingeriana $(45 \%)+1,3 \mathrm{ml}$ probiotik/kg substrat; dan E: Pelepah kelapa sawit $(0 \%)+I$. zollingeriana $(100 \%)+1,3 \mathrm{ml}$ probiotik/kg substrat. Hasil penelitian menunjukkan bahwa kandungan NDF, ADF dan ADL pelet silase pelepah kelapa sawit nyata $(\mathrm{P}<0,05)$ lebih tinggi dari kandungan NDF silase pelet I. zollingeriana. Penambahan I. zollingeriana pada taraf 30 dan $45 \%$ nyata menurunkan kandungan NDF, ADF dan ADL pelet silase berbahan dasar pelepah kelapa sawit. Berdasarkan data hasil penelitian dapat disimpulkan bahwa meningkatnya proporsi $I$. zollingeriana sampai $45 \%$ menghasilkan pelet silase pelepah kelapa sawit dengan kandungan NDF, $\mathrm{ADF}$ dan ADL yang semakin rendah.
\end{abstract}

Kata Kunci: Pelepah Kelapa Sawit, Indigofera zollingeriana, Fraksi Serat 


\section{PENDAHULUAN}

Pakan merupakan salah satu faktor penentu utama yang mempengaruhi keberhasilan suatu usaha peternakan, sehingga perlu adanya perhatian dalam ketersediaan pakan baik dari segi kualitas maupun kuantitas. Pemberian pakan yang berkualitas dan sesuai dengan kebutuhan ternak akan menghasilkan ternak yang memiliki produktivitas yang tinggi. Pada saat musim hujan ketersediaan hijauan melimpah, sedangkan saat musim kemarau ketersediaannya terbatas dan nilai gizinya rendah. Oleh karena itu, diperlukan pakan alternatif untuk mengatasi persoalan tersebut. Salah satu alternatif penyediaan hijauan pakan ternak ruminansia adalah dengan memanfaatkan limbah pertanian. Pemanfaatan limbah pertanian sebagai pakan untuk ternak ruminansia telah dikenal luas. Hal ini dikarenakan kemampuan ternak ruminansia mengkonversi bahan pakan yang mengandung serat kasar tinggi menjadi produk-produk yang bermanfaat untuk pertumbuhan dan reproduksi. Salah satu limbah pertanian yang cukup potensial untuk dijadikan pakan ternak ruminansia adalah pelepah kelapa sawit (Djajanegara \& Juniar, 2000).

Pelepah kelapa sawit merupakan salah satu limbah perkebunan hasil pemangkasan kelapa sawit yang pemanfaatannya kurang mendapat perhatian oleh petani. Pelepah kelapa sawit dapat dijadikan sumber cadangan pakan hijauan untuk ternak ruminansia dan juga berfungsi menghindari berkembangnya hewan pengganggu seperti tikus, ular dan hama lainnya (Liang 2009). Berdasarkan data BPS (2016) luas perkebunan kelapa sawit di Provinsi Riau terus mengalami perkembangan. Pada tahun 2012 luas perkebunan kelapa sawit di Provinsi Riau 2.139.820 ha dan pada tahun 2015 meningkat menjadi 2.381 .900 ha. Setiap pohon kelapa sawit mampu menghasilkan 22 pelepah/tahun dan rata-rata bobot pelepah per batang mencapai $2,2 \mathrm{~kg}$ setelah dikupas untuk pakan, sehingga setiap hektar dapat menghasilkan pelepah segar untuk pakan ternak sekitar 9 ton/ha/tahun atau setara dengan 1,64 ton/ha/tahun bahan kering (Diwyanto et al. 2003). Pelepah kelapa sawit dapat dipergunakan sebagai sumber pengganti hijauan atau dapat diberikan dalam bentuk silase yang dikombinasikan dengan bahan lain atau konsentrat sebagai campuran (Mathius et al. 2003). Pelepah kelapa sawit dapat digunakan sebagai bahan pakan substitusi rumput dengan pemberian sebesar 30-60\% (Elisabeth \& Ginting 2003). Komposisi nutrisi pelepah sawit adalah protein kasar (PK) 10,15\%, lemak kasar (LK) 3,11\%, serat kasar (SK) 32,64\%, abu 7,70\% dan Total Digestible Nutrient (TDN) 67\% dan Beta-N 49,69\% (Dinas PKH Provinsi Riau 2013). Serat kasar merupakan komponen penyusun terbesar dari pelepah sawit, dimana komponen fraksi serat pelepah sawit terdiri dari selulosa, hemiselulosa, lignin dan silika (Elisabeth \& Ginting 2003). Berdasarkan penelitian Simanihuruk et al. (2008), pelepah kelapa sawit yang telah menjadi silase mengandung bahan kering (BK) 30,90\%; Abu 11,73\%; PK 4,57\%; Neutral Detergent Fiber (NDF) 58,73\% dan Acid Detergent Fiber (ADF) 37,36\%. Berdasarkan potensi pelepah kelapa sawit tersebut bila diberikan kepada ternak ruminansia perlu dikombinasikan dengan bahan pakan yang tinggi kandungan protein kasarnya salah satunya adalah Indigofera zollingeriana. Indigofera zollingeriana dapat dikembangkan di daerah tropis dengan produksi daun mencapai $4.096 \mathrm{~kg} \mathrm{BK} / \mathrm{ha}$ (Abdullah 2010) sedangkan kandungan NDF Indigofera tergolong rendah yaitu antara 22\%-46\% (Hassen et al. 2007). Indigofera zollingeriana dapat tumbuh pada ketinggian antara 0-2200 $\mathrm{m} \mathrm{dpl,} \mathrm{dengan} \mathrm{curah} \mathrm{hujan}$ antara 600-3.000 mm/tahun dan laju pertumbuhan, produksi biomassa dan kandungan nutrisinya lebih besar dibandingkan dengan jenis leguminosa pohon lain pada kondisi tanah dan iklim yang sama (Herdiawan \& Krisnan 2014). Tepung daun Indigofera sp. mengandung PK sebesar 27,9\%; SK sebesar 15,25\%; Ca 0,22\% dan P 0,18\% (Abdullah 2010). Indigofera yang berkualitas tinggi sangat potensial dijadikan biomassa untuk meningkatkan kandungan nutrisi pelepah kelapa sawit yang berkualitas rendah melalui 
proses fermentasi kemudian dijadikan pakan berbentuk pelet. Menurut Hartadi et al. (1990) pelet dikenal sebagai bentuk masa dari bahan pakan atau ransum yang dibentuk dengan cara menekan dan memadatkan melalui lubang cetakan secara mekanis.

Beberapa keuntungan pembuatan pelet pada bahan pakan kasar meliputi pakan lebih seragam sehingga mengurangi seleksi pakan oleh ternak, meningkatkan kerapatan jenis, mengurangi debu pakan yang telah digiling, memudahkan penanganan dan mengurangi bahan pakan yang terbuang. Penelitian ini bertujuan untuk mengetahui pengaruh penambahan I. zollingeriana terhadap kandungan NDF, ADF dan acid detergent lignin (ADL) pelet silase berbahan dasar pelepah kelapa sawit.

\section{MATERI DAN METODE}

\section{Tempat dan waktu penelitian}

Pembuatan pelet dilakukan di Laboratorium Agrostologi, Industri Pakan dan Ilmu Tanah. Analisis kandungan fraksi serat dilakukan di Laboratorium Ilmu Nutrisi dan Kimia, Fakultas Pertanian dan Peternakan, Universitas Islam Negeri Sultan Syarif Kasim Riau.

\section{Bahan dan alat penelitian}

Bahan pakan utama yang digunakan pada penelitian ini adalah pelepah dan daun kelapa sawit yang tumbuh di kota Pekanbaru dan I. zollingeriana yang tumbuh di kebun percobaan Laboratorium Agrostologi, Industri Pakan dan Ilmu Tanah, Fakultas Pertanian dan Peternakan, Universitas Islam Negeri Sultan Syarif Kasim Riau. Untuk penyempurnaan dan mempercepat proses fermentasi juga digunakan probiotik komersial serta tepung tapioka sebagai bahan perekat pelet. Alat yang digunakan untuk proses pembuatan silase adalah mesin pencacah (chopper) dan timbangan. Alat yang digunakan untuk pembuatan pakan berbentuk pelet adalah mixer dan mesin pencetak pelet.

\section{Metode penelitian}

Penelitian ini dilakukan dengan menggunakan Rancangan Acak Lengkap (RAL) yang terdiri dari 5 perlakuan dengan 3 ulangan. Perlakuan terdiri dari: A: Pelepah kelapa sawit $(100 \%)+$ I. zollingeriana $(0 \%)+1,3 \mathrm{ml}$ probiotik/kg substrat (kontrol 1); B: Pelepah kelapa sawit $(85 \%)+$ I. zollingeriana $(15 \%)+1,3 \mathrm{ml}$ probiotik $/ \mathrm{kg}$ substrat; C: Pelepah kelapa sawit $(70 \%)+$ I. zollingeriana $(30 \%)+1,3 \mathrm{ml}$ probiotik/kg substrat; D: Pelepah kelapa sawit $(55 \%)+I$. zollingeriana $(45 \%)+1,3 \mathrm{ml}$ probiotik/kg substrat; dan E: Pelepah kelapa sawit $(0 \%)+$ I. zollingeriana $(100 \%)+1,3 \mathrm{ml}$ probiotik/kg substrat (kontrol 2).

\section{Prosedur penelitian}

Fermentasi pada setiap kombinasi perlakuan dilakukan secara anaerob pada suhu ruang selama 21 hari. Sebelum dibuat pakan berbentuk pelet, silase dikeringkan di bawah sinar matahari sampai beratnya konstan, selanjutnya digiling sampai berbentuk tepung, kemudian dibuat adonan dengan menambahkan tepung tapioka sebagai bahan perekat dan air secukupnya lalu dicetak dengan mesin pelet (pelleter), lalu dijemur di bawah sinar matahari sampai kering. Fraksi serat berupa NDF, ADF dan ADL diukur menurut metode Van Soest et al. (1991). 


\section{Analisis statistik}

Data hasil percobaan dianalisis secara statistik dengan menggunakan analysis of varian (ANOVA). Apabila terdapat perbedaan yang nyata antar perlakuan maka dilanjutkan dengan uji jarak Duncan's multiple range test (DMRT) pada tingkat 5\% $(\mathrm{P}<0,05)$.

\section{HASIL DAN PEMBAHASAN}

\section{Kandungan NDF pelet}

Data hasil penelitian (Tabel 1) menunjukkan bahwa kandungan NDF pelet silase pelepah kelapa sawit $(\mathrm{A})$ nyata $(\mathrm{P}<0,05)$ lebih tinggi dari kandungan NDF silase pelet $I$. zollingeriana $(\mathrm{E})$. Lebih rendahnya kandungan $\mathrm{NDF}$ perlakuan $\mathrm{E}$ dibandingkan dengan perlakuan A disebabkan adanya perbedaan karakteristik dinding sel antara I. zollingeriana dan pelepah kelapa sawit. Tanaman leguminosa (I. zollingeriana) mempunyai kandungan pektin yang sangat besar dalam dinding sel utamanya (Jung \& Casler 2006) sehingga persentase material dinding selnya lebih rendah dibandingkan pelepah kelapa sawit.

Tabel 1. Rata-rata NDF pelet silase pelepah kelapa sawit dan I. zollingeriana

\begin{tabular}{lc}
\hline \hline Perlakuan & NDF $(\%)$ \\
\hline A (100\% pelepah kelapa sawit $+0 \%$ I. zollingeriana) & $66,04^{\mathrm{d}} \pm 3,77$ \\
B (85\% pelepah kelapa sawit $+15 \%$ I. zollingeriana) & $55,33^{\mathrm{c}} \pm 1,39$ \\
C (70\% pelepah kelapa sawit $+30 \%$ I. zollingeriana) & $47,77^{\mathrm{b}} \pm 3,37$ \\
D (55\% pelepah kelapa sawit $+45 \%$ I. zollingeriana) & $48,07^{\mathrm{b}} \pm 4,36$ \\
E (0\% pelepah kelapa sawit $+100 \%$ I. zollingeriana) & $33,96^{\mathrm{a}} \pm 1,89$ \\
\hline
\end{tabular}

Semua perlakuan ditambahkan $1,3 \mathrm{ml}$ probiotik/kg substrat; Superskrip yang berbeda pada kolom yang sama menunjukkan perbedaan nyata $(\mathrm{P}<0,05)$

Penambahan probiotik dalam proses fermentasi secara anaerob pada penelitian ini menunjukkan hasil yang lebih baik dibanding dengan tanpa penambahan probiotik. Penelitian Ali et al. (2015) mendapatkan bahwa dengan penambahan 5\% molases kandungan NDF silase pelebah sawit $74,41 \%$. Sementara itu, dengan penambahan sebanyak $1,3 \mathrm{ml}$ probiotik/kg substrat hasil penelitian ini mendapatkan kandungan NDF pelet silase pelepah sawit $66,04 \%$. Hal ini menunjukkan bahwa penambahan probiotik dapat menurunkan fraksi serat dinding sel pelepah sawit.

Penambahan I. zollingeriana pada taraf 15, 30 dan $45 \%$ nyata menurunkan kandungan NDF pelet silase berbahan dasar pelepah kelapa sawit. Hasil ini memperkuat hasil-hasil penelitian sebelumnya, dimana penambahan hijauan pakan yang mempunyai kandungan protein kasar (PK) yang tinggi seperti tanaman leguminosa dapat menurunkan kandungan serat dan meningkatkan kandungan protein kasar bahan pakan berserat tinggi (Benavides 2006). Hasil penelitian Darwanta et al. (2016) mendapatkan bahwa penambahan $I$. zollingeriana sampai taraf $45 \%$ dapat meningkatakan kandungan PK pelet silase pelepah kelapa sawit dari 8,47 menjadi 14,59\% dan menurunkan kandungan serat kasar (SK) dari 22,87 menjadi 16,55\%. Hasil ini juga membuktikan bahwa kandungan PK berhubungan terbalik dengan kandungan SK. Kandungan NDF pelet silase berbahan dasar pelepah kelapa sawit hasil penelitian ini masih berada dalam batas yang aman untuk diberikan ke ternak ruminansia. Secara normal persentase NDF yang aman untuk diberikan ke ternak adalah adalah 36,7-66,6\% (NRC 2001). 


\section{Kandungan ADF pelet}

Data hasil penelitian (Tabel 2) menunjukkan bahwa kandungan ADF pelet silase pelepah kelapa sawit $(\mathrm{A})$ nyata $(\mathrm{P}<0,05)$ lebih tinggi dari kandungan ADF silase pelet $I$. zollingeriana $(\mathrm{E})$. Lebih rendahnya kandungan $\mathrm{ADF}$ perlakuan E dibandingkan dengan perlakuan A mungkin disebabkan oleh lebih tingginya kandungan protein kasar (PK) $I$. zollingeriana dibandingkan dengan pelepah kelapa sawit. Kandungan PK berhubungan negatif dengan kandungan fraksi serat. Bila kandungan PK hijauan pakan tinggi maka kandungan fraksi serat cenderung lebih rendah. ADF adalah bagian dari fraksi serat dimana unsur utamanya adalah selulosa (Ali 2014).

Penambahan probiotik dalam proses fermentasi secara anaerob pada penelitian ini juga menunjukkan hasil yang lebih baik dalam menurunkan kandungan ADF pelet silase pelepah kelapa sawit dibandingkan dengan tanpa penambahan probiotik. Penelitian Ali et al. (2015) mendapatkan bahwa dengan penambahan 5\% molases kandungan ADF silase pelepah sawit $56,22 \%$. Sementara itu, dengan penambahan sebanyak $1,3 \mathrm{ml}$ probiotik $/ \mathrm{kg}$ substrat hasil penelitian ini mendapatkan kandungan ADF pelet silase pelepah sawit $44,82 \%$. Hasil ini menunjukkan bahwa penambahan probiotik dapat meningkatkan produktivitas mikroorganisme dalam merombak dinding sel bahan pakan.

Tabel 2. Rata-rata ADF pelet silase pelepah kelapa sawit dan I. zollingeriana

\begin{tabular}{lc}
\hline \hline Perlakuan & ADF $(\%)$ \\
\hline A (100\% pelepah kelapa sawit $+0 \%$ I. zollingeriana) & $44,82^{\mathrm{d}} \pm 3,97$ \\
B (85\% pelepah kelapa sawit $+15 \%$ I. zollingeriana) & $36,54^{\mathrm{c}} \pm 1,92$ \\
C (70\% pelepah kelapa sawit $+30 \%$ I. zollingeriana) & $36,11^{\mathrm{c}} \pm 5,37$ \\
D (55\% pelepah kelapa sawit $+45 \%$ I. zollingeriana) & $27,41^{\mathrm{b}} \pm 2,49$ \\
E (0\% pelepah kelapa sawit $+100 \%$ I. zollingeriana) & $17,41^{\mathrm{a}} \pm 4,12$ \\
\hline
\end{tabular}

Semua perlakuan ditambahkan $1,3 \mathrm{ml}$ probiotik/kg substrat; Superskrip yang berbeda pada kolom yang sama menunjukkan perbedaan nyata $(\mathrm{P}<0,05)$

Penambahan I. zollingeriana pada taraf 15,30 dan $45 \%$ nyata $(\mathrm{P}<0,05)$ menurunkan kandungan ADF pelet silase berbahan dasar pelepah kelapa sawit. Hasil ini menunjukkan bahwa untuk meningkatkan kecernaan bahan yang berserat tinggi dapat dilakukan dengan penambahan tanaman leguminosa. Kandungan ADF menggambarkan kualitas dinding sel hijauan. Bagian ini terdiri dari selulosa dan lignin. Dengan menurunnya kandungan ADF maka kecernaan pelet silase berbahan dasar pelepah kelapa sawit akan meningkat. Hal ini sesuai dengan pendapat Ruddel et al. (2002) bahwa persentasi ADF yang tinggi akan menurunkan daya cerna bahan pakan.

\section{Kandungan ADL pelet}

Data hasil penelitian (Tabel 3) menunjukkan bahwa kandungan ADL pelet silase pelepah kelapa sawit $(\mathrm{A})$ nyata $(\mathrm{P}<0,05)$ lebih tinggi dari kandungan ADL silase pelet $I$. zollingeriana $(\mathrm{E})$. Sehingga peningkatan level penambahan I. zollingeriana nyata $(\mathrm{P}<0,05)$ menurunkan kandungan ADL pelet silase berbahan dasar pelepah kelapa sawit. Penurunan kandungan ADL diduga berkaitan dengan penurunan kandungan ADF yang disebabkan oleh peningkatan level penambahan I. zollingeriana. Apabila kandungan ADF mengalami penurunan maka kandungan ADL juga diperkirakan akan menurun karena ADL merupakan bagian dari ADF. Suparjo et al. (2011) menyatakan perombakan dinding sel 
dan isi sel menyebabkan larutnya komponen kristal selulosa, lignin dan silika yang merupakan bagian dari ADF. Penurunan kandungan ADL ini akan menyebabkan kecernaan pelet silase pelepah kelapa sawit meningkat. Hasil penelitian Roflimas (2015) mendapatkan bahwa penambahan biomasa $I$. zollingeriana sebanyak $45 \%$ dapat menurunkan kandungan ADL silase pelepah kelapa sawit dan meningkatkan kecernaan bahan kering in vitro (KCBKIV) dari 47,74 menjadi 57,44\% serta meningkatkan kecernaan bahan organik in vitro (KCBOIV) dari 46,94 menjadi 56,44\%.

Penambahan probiotik dalam proses fermentasi secara anaerob pada penelitian ini dapat menurunkan kandungan ADL yang lebih baik dibandingkan tanpa penambahan probiotik. Penelitian Ali et al. (2015) mendapatkan bahwa dengan penambahan 5\% molases kandungan ADL silase pelepah sawit turun dari 18,74 menjadi 12,81\%. Sementara itu dengan penambahan sebanyak $1,3 \mathrm{ml}$ probiotik/kg substrat hasil penelitian ini mendapatkan kandungan ADL pelet silase pelepah sawit turun dari 19,85 menjadi $8,93 \%$. Hasil ini menunjukkan bahwa pemakaian probiotik dalam proses fermentasi secara anaerob dapat meningkatkan perombakan dinding sel dan kelarutan komponen kristal penyusun dinding sel seperti lignin.

Tabel 3. Rata-rata ADL pelet silase pelepah kelapa sawit dan I. zollingeriana

\begin{tabular}{lc}
\hline \hline Perlakuan & ADL $(\%)$ \\
\hline A (100\% pelepah kelapa sawit $+0 \%$ I. zollingeriana $)$ & $19,85^{\mathrm{c}} \pm 1,91$ \\
B (85\% pelepah kelapa sawit $+15 \%$ I. zollingeriana) & $17,31^{\mathrm{c}} \pm 1,92$ \\
C (70\% pelepah kelapa sawit $+30 \%$ I. zollingeriana) & $12,68^{\mathrm{b}} \pm 2,35$ \\
D (55\% pelepah kelapa sawit $+45 \%$ I. zollingeriana $)$ & $8,93^{\mathrm{a}} \pm 2,26$ \\
E (0\% pelepah kelapa sawit $+100 \%$ I. zollingeriana) & $5,61^{\mathrm{a}} \pm 1,82$ \\
\hline
\end{tabular}

Semua perlakuan ditambahkan $1,3 \mathrm{ml}$ probiotik/kg substrat; Superskrip yang berbeda pada kolom yang sama menunjukkan perbedaan nyata $(\mathrm{P}<0,05)$

\section{KESIMPULAN}

Berdasarkan data hasil penelitian dapat disimpulkan bahwa meningkatnya proporsi $I$. zollingeriana sampai $45 \%$ menghasilkan pelet silase pelepah kelapa sawit dengan kandungan NDF, ADF dan ADL yang semakin rendah.

\section{DAFTAR PUSTAKA}

Abdulah 1. 2010. Herbage production and quality of shrub indigofera treated by different cocentration of foliar fertilizer. Media Peternakan.33:169-175.

Ali A. 2014. Sistem penanaman campuran rumput dan leguminosa di lahan gambut untuk produksi hijauan pakan ternak berkelanjutan [Disertasi]. [Bogor (Indonesia)]: Institut Pertanian Bogor.

Ali A, Maulidayanti, Elviriadi, Misrianti R. 2015. Fraksi serat silase pelepah kelapa sawit dengan penambahan biomassa indigofera. Dalam: Revitalisai Peternakan Berbasis Sumberdaya Ternak Lokal dalam Menghadapi MEA. Prosiding Seminar Nasional II Pengembangan Ternak Lokal. Padang, 25-26 November 2015. Padang (Indonesia) Fakultas Peternakan Universitas Andalas Padang. hlm.332-340.

BPS. 2016. Luas tanaman perkebunan menurut propinsi dan jenis tahaman tahun 2012-2015. Jakarta (Indonesia): Badan Pusat Statistik. 
Benavides J, Hernandez I, Esquivel J, Vasconcelos J. 2002. Supplementation of grazing dairy cattle with mulberry in Costa Rica. In: Sanchez MD, editor. Mulberry for animal production. Animal Production and Health Paper No. 147. Rome (Italy): FAO. p. 165-170.

Darwanta J, Ali A, Misrianti R. 2016. Kualitas nutrisi pelet silase pelepah kelapa sawit dengan penambahan biomassa indigofera (Indigofera zollingeriana). Dalam: Prosiding Seminar Nasional Pertanian dan Peternakan. Pekanbaru (Indonesia): Fakultas Pertanian dan Peternakan UIN Suska Riau. hlm. 185-190.

Diwyanto K, Sitompul D, Mantis, Mathius IW, Soentoro. 2003. Pengkajian pengembangan usaha sistem integrasi kelapa sawit. Dalam: Prosiding Lokakarya Sistem Integrasi Kelapa SawitSapi. Bengkulu, 9-10 September 2003. Bengkulu (Indonesia): Departemen Pertanian Bekerjasama dengan Pemerintah Provinsi Bengkulu dan PT Agricinal. hlm. 11-22.

Dinas PKH Provinsi Riau. 2013. Laporan akhir analisis bahan pakan. Riau (Indonesia): Kerjasama Dinas Peternakan dan Kesehatan Hewan Provinsi Riau dengan Fakultas Peternakan Institut Pertanian Bogor.

Djajanegara A, Sirait J. 2000. Kelayakan ekonomi usaha daun kelapa sawit sebagai sumber pakan ternak ruminansia. Laporan bagian proyek rekayasa teknologi peternakan Armp-Ii. hlm. 187190.

Elisabeth J, Ginting SP. 2003. Pemanfaatan hasil samping industri kelapa sawit sebagai bahan pakan ternak sapi potong. Dalam: Prosiding Lokakarya Sistem Integrasi Kelapa Sawit-Sapi. Bengkulu, 9-10 September 2003. Bengkulu (Indonesia): Departemen Pertanian Bekerjasama dengan Pemerintah Provinsi Bengkulu dan PT Agricinal.

Hartadi N, Reksohadripodjo S, Tillman AD. 1990. Tabel komposisi pakan untuk Indonesia. Yogyakarta (Indonesia): Gadjah Mada Universitas Press.

Hassen A, Rethman NFG, Tjelele TJ. 2007. Influence of season/year and species on chemical composition and in vitro digestibility of five Indigofera accessions. Anim Feed Sci Technol. $136: 312-322$.

Herdiawan I, Krisnan R. 2014. Produktivitas dan pemanfaatan tanaman leguminosa pohon Indigofera zollingeriana pada lahan kering. Wartazoa. 24:75-82.

Jung HG, Casler MD. 2006. Maize stem tissues: Cell wall concentration and composition during development. Crop Sci. 46:1793-1800.

Liang T. 2009. Seluk beluk kelapa sawit. Ketapang (Indonesia): Harapan Sawit Lestari.

Mathius IW, Manurung DBP, Asmi. 2003. Produk samping tanaman dan pengolahan buah kelapa sawit sebagai bahan dasar pakan komplit: Suatu tinjauan. Dalam: Prosiding Lokakarya Sistem Integrasi Kelapa Sawit-Sapi. Bengkulu, 9-10 September 2003. Bengkulu (Indonesia): Departemen Pertanian Bekerjasama dengan Pemerintah Provinsi Bengkulu dan PT Agricinal. hlm. 120-128.

NRC. 2001. Nutrient requirement of dairy cattle. Washington DC (US): National Research Council. National Academies Press.

Ruddel A, Filley S, Porat M. 2002. Understanding your foragr test result. Oregon (US): Oregon State University.

Roflimas. 2016. Kecernaan in vitro pelet silase pelepah kelapa sawit dengan penambahan biomassa Indigofera [Skripsi]. [Pekanbaru (Indonesia)]: Fakultas Pertanian dan Peternakan, UIN Suska Riau.

Simanihuruk K, Junjungan, Ginting SP. 2008. Pemanfaatan silase pelepah kelapa sawit sebagai pakan basal kambing kacang fase pertumbuhan. Dalam: Sani Y, Martindah E, Nurhayati, Puastuti W, Sartika T, Parede L, Anggraeni A, Natalia L, penyunting. Inovasi Teknologi Mendukung Pengembangan Agribisnis Peternakan Ramah Lingkungan. Prosiding Seminar 
Nasional Teknologi Peternakan dan Veteriner. Bogor, 11-12 November 2008. Bogor (Indonesia): Puslitbangnak. hlm. 446-455.

Suparjo, Wiryawan KG, Laconi EB, Mangunwidjaja D. 2011. Performans kambing yang diberi kulit buah kakao terfermentasi. Media Peternakan. 34:35-41.

Van Soest PJ, Robertson JB, Lewis BA. 1991. Methods for dietary fiber, neutral detergent fiber and non-starch polysaccharides in relation to animal nutrition. J Dairy Sci. 74:3583-3593.

\section{DISKUSI}

\section{Pertanyaan}

1. Kendala di lapang shredder belum bisa halus?

2. Perlu diperhatikan biaya harus efisien untuk peternak.

3. Proses pelet dengan pemanasan apakah mempengaruhi palatabilitas?

4. Apakah nama probiotik yg digunakan?

\section{Jawaban}

1. Tidak mempengaruhi.

2. Perlu dihitung nilai ekonomi dari pelepah sawit setelah difermentasi.

3. Hasil fermentasi sudah diaplikasikan ke ternak dan palatabilitas cukup baik.

4. Probiotik yg digunakan adalah Yakult. 